\title{
Paleobiology of the genus Hypericum (Hypericaceae): a survey of the fossil record and its palaeogeographic implications
}

\author{
Andrea S. Meseguer* \& Isabel Sanmartín \\ Real Jardín Botánico, CSIC, Plaza de Murillo 2, E-28014 Madrid, Spain. ameseguer@rjb.csic.es; isanmartin@rjb.csic.es
}

\begin{abstract}
Meseguer, A.S. \& Sanmartín, I. 2012. Paleobiology of the genus Hypericum (Hypericaceae): a survey of the fossil record and its palaeogeographic implications. Anales Jard. Bot. Madrid 69(1): 97-106

Genus Hypericum is one of the 100 largest genera in angiosperms with nearly 500 species. Despite its worldwide, nearly cosmopolitan distribution and apparently old age - there are fossil remains of relatives from the Mid Cretaceous - the fossil record of Hypericum has been largely overlooked in phylogenetic studies. Here, we survey the fossil record of Hypericum from the literature, with special emphasis on the oldest fossil remain, Hypericum antiquum, from which we reassess its diagnostic characters. We evaluate the implications of this record in reconstructing the past geographic distribution of genus Hypericum.
\end{abstract}

Keywords: boreotropical, fossil, Hypericum, palaeogeography, pollen, seeds.

\section{INTRODUCTION}

Hypericum L. is a large genus containing nearly 500 species (Nürk \& Blattner, 2010; Robson, 2010). The genus comprises large shrubs, small trees or rhizomatous, sometimes annual, herbs, with yellow flowers and frequently glandulous tepals or leaves. It has a worldwide distribution, with representatives in nearly every continent, being only absent from the poles, deserts, and low-altitude tropical areas (Fig. 1). Nowadays, the largest diversity in the genus is found in the Northern Hemisphere (Eurasia and North America), but it is also abundant in high-altitude tropical areas of the Southern Hemisphere, such as the tropical Andes in South America or the Eastern African Mountains (Robson, 1977). Some species of Hypericum, like H. perforatum, have been used in traditional medicine based on the pharmacological properties of their active compounds, hypericine and pseudo-hypericine, which are used as painkillers, antidepressants or anticancer treatments (Matzk \& al., 2001).

The taxonomic adscription of the genus Hypericum has long been discussed, with the genus being classified as either a tribe or a subfamily inside a broadly defined family Clusia-ceae (Robson, 1977). The most recent taxonomic

\section{Resumen}

Meseguer, A.S. \& Sanmartín, I. 2012. Paleobiología del género Hypericum (Hypericaceae): una revisión del registro fósil y sus implicaciones paleogeográficas. Anales Jard. Bot. Madrid 69(1): 97-106 (en inglés)

El género Hypericum contiene 500 especies aproximadamente y es uno de los 100 géneros más grandes dentro de las angiospermas. A pesar de que tiene una distribución cosmopolita y de que es presumiblemente muy antiguo -existen restos fósiles de grupos emparentados filogenéticamente del Cretácico medio- el registro fósil de Hypericum no ha sido utilizado en estudios filogenéticos. En este trabajo hacemos una revisión de la literatura sobre el registro fósil de Hypericum con especial énfasis en los restos más antiguos de la especie Hypericum antiquum, del que reevaluamos sus caracteres diagnósticos. Finalmente, discutimos las implicaciones que este registro fósil tiene en la reconstrucción paleogeográfica del género Hypericum.

Palabras clave: boreotropical, fósil, Hypericum, paleogeografía, polen, semillas.

treatment (Stevens, 2007) considers Hypericum as a genus inside the family Hypericaceae. This family includes three tribes: Hypericeae, which has a nearly cosmopolitan distribution and includes five genera (Hypericum, Triadenum, Thornea, Santomasia, and Lianthus), and the tropical tribes Cratoxyleae (Eliea and Cratoxylon) and Vismieae (Harungana, Vismia and Psorospermum). Recent phylogenetic revisions based on morphological (Nürk \& Blattner, 2010) and molecular characters (Ruhfel \& al., 2011) have shown that genus Hypericum is not monophyletic, and that other members of tribe Hypericeae (Triadenum, Santomasia and Thornea) are nested within it. Therefore, throughout this work we will refer to Hypericeae as a synonym to Hypericum.

Although no attempt has been made yet to reconstruct the temporal evolution of Hypericum (Meseguer \& al., in prep.), there is indirect evidence that the genus is rather old. The order Malpighiales, to which family Hypericaceae belongs to together with families Clusiaceae, Malpighiaceae and Bonnetiaceae, among others - began its diversification in the Early Cretaceous, as evidenced by the presence of a Mid-Cretaceous fossil, Paleoclusia chevalieri (Crepet \& Nixon, 1998) and by molecular phylogenetic estimates of divergence times (Davis \& al., 2005). The latter study estimates the age of the 


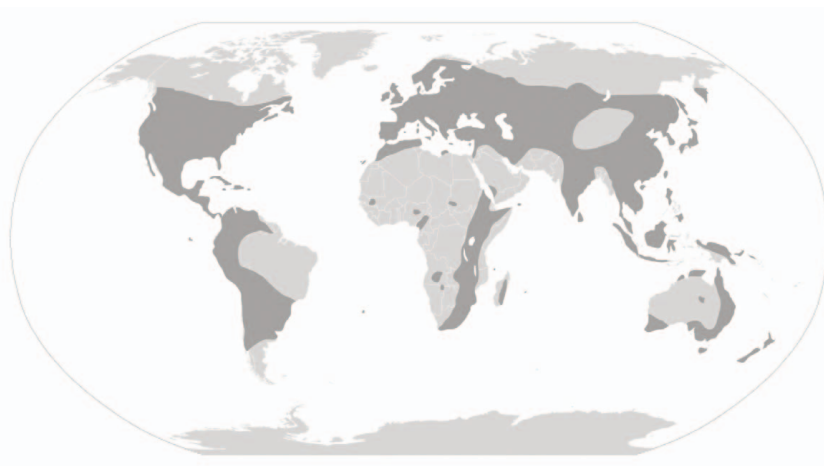

Fig. 1. Map showing the present distribution of Hypericum species (adapted from Robson, 1977).

split of Hypericaceae and its sister group Podostemaceae around the Late Cretaceous, ca. 76 millions of years $(\mathrm{Ma})$.

Despite the presumably old age, worldwide distribution, and the ancient radiation of sister families, the fossil record of Hypericum has been mostly overlooked in phylogenetic studies. In what it is still the most exhaustive taxonomic revision of the genus, Robson (1981, pg. 65) wrote "In the absence of a useful fossil record - and with the possible exception of Pliocene seeds (see e.g. Reid, 1923), there are no known fossils of Hypericum..." Subsequent researchers have also assumed that Hypericum lacks a useful fossil record for phylogenetic purposes (Stevens, 2007). This is surprising, since a quick search in the Paleobiology Database (http://paleodb.org) found nearly 70 collections (95 occurrences) from the Upper Eocene onwards. It should be noted, however, that many of these fossils are microfossils (seeds and pollen), and that the material is often fragmented or not well preserved, which makes difficult to assign the fossil to a particular taxon.

Fossil remains can provide calibration points to estimate lineage divergence times from molecular-measured branch lengths in a phylogenetic analysis, the "so-called" molecular clock. In recent years, there have been important advances to incorporate the uncertainty in fossil calibrations ("stratigraphic ages") to phylogenetic dating (Ho, 2007). Likewise, fossils can be used to pinpoint the geographic location of now-extinct ancestral lineages - which does not necessarily coincide with the distribution of the extant taxa - and this in turn can provide valuable information concerning the climatic preferences of the group. Here, we survey the fossil record of Hypericum from the literature, with special focus in the oldest fossil described (H. antiquum Balueva \& V.P. Nikitin), and reassess some diagnostic characters used for the taxonomic assignment to extant taxa, as a first step to employ these fossils in reconstructing the spatio-temporal evolution of the genus (Meseguer \& al., in prep.).

\section{MATERIAL AND METHODS}

We searched the available paleobiological literature for Hypericum and other genera of tribe Hypericeae, especially through the online resource Paleobiology Database (http://paleodb.org), as well as other original publications describing fossil taxa of Hypericum not included in the referred database. In addition, to assess the main diagnostic features of seeds of extant Hypericum species, we used a Zeiss stereomicroscopy attached to a digital camera ("STEMI 2000-C-ZEISS) for describing and documenting fine details of specimens preserved in MA. Microscopic features of the seed surface were photographed with a Hitachi S3000N digital Scanning Electron Microscope at the facilities of the Real Jardín Botánico de Madrid, CSIC; prior to visualization, seed specimens were treated using a Balzers SDC004 sputter coater for sample gold-coating.

\section{POLLEN AND SEED MORPHOLOGY}

Before reviewing the fossil record of Hypericum, we will describe the morphology and main diagnostic features of the seeds and pollen of extant species of Hypericum, since these remains are the most common fossil records attributed to the genus.

\section{Pollen morphology}

Pollen grains in the genus Hypericum have been studied in several works (Khan, 1969; Thomas, 1970; Clarke, 1975; 1976, 1981; Barros \& Ramos, 1984; Mártonfi \& al., 2002). The standard type of the group is a regular 3 -zonocolporate with a microreticulate to reticulate ornamentation pattern. The only divergence within Hypericum from the standard tricolporate plan characteristic of angiosperms is a tendency of some species to produce grains with more than three apertures and loosed strict polarity (Clarke, 1981). Although the presence of irregular pollen grains have been frequently cited within the genus (Clarke, 1975; Mártonfi \& al., 2002), among regular grains a set of different basic types can be distinguished. Clarke (1981) described eleven distinct pollen types that are more or less uniform within the defined morphological sections. The only exceptions are sections Ascyreia, Triadenioides, Adenosepalum, Hypericum and Hirtella whose species present pollen from different morphotypes (Table 1).

Despite the discreteness of the different pollen types within Hypericum, the basic plan is not particularly distinctive from other angiosperm lineages, which makes fossil seeds a potentially more powerful source of paleobiological information (Clarke, 1981). On the other hand, fossil pollen is not as useful as seeds to associate ancestors to a particular place in space, since pollen grains can occasionally travel long distances and be found far away from the species original distribution.

\section{Seed morphology}

In angiosperms, the seed coat is usually divided into a testa and a tegmen, and both can be further divided into different epidermal layers. The seeds of the family Hypericaceae are exotegmal, which means that the mechanical tissue is developed in the outer layer of the tegmen, and the cells develop into a palisade of tubular or radially elongated cells, with stellate-undulate or lobate facetes (Corner, 1976a, 1976b). According to Corner (1976a), the shape of the exotegmic 
Table 1. Basic pollen types in Hypericum sections. Adapted from Clarke (1981).

\begin{tabular}{|c|c|c|}
\hline $\begin{array}{l}\text { Pollen } \\
\text { type }\end{array}$ & Description & Morphological section \\
\hline 1 & $\begin{array}{l}\text { Grains: prolate-spheroidal to subprolate. } \\
\text { Endoaperture: a porus with very small lateral extensions. } \\
\text { Ornamentation: a tectum perforatum or microreticulum; tectal perforations regularly spaced. }\end{array}$ & $\begin{array}{l}\text { Campylosporus, Webbia, } \\
\text { Adenosepalum, Ascyreia }\end{array}$ \\
\hline 2 & $\begin{array}{l}\text { Grains: prolate-spheroidal to subprolate. } \\
\text { Endoaperture: a porus, often more or less lalongate (transversally elongated), } \\
\text { with very small lateral extensions. } \\
\text { Ornamentation: a tectum perforatum or microreticulum; tectal perforations grouped } \\
\text { together. }\end{array}$ & Ascyreia \\
\hline 3 & $\begin{array}{l}\text { Grains: subprolate. } \\
\text { Endoaperture: a lalongate colpus. } \\
\text { Ornamentation: a tectum perforatum or microreticulum; tectal perforations grouped } \\
\text { together. }\end{array}$ & $\begin{array}{l}\text { Ascyreia, Takasagoya, Roscyna, } \\
\text { Inodorum, Androsaemum }\end{array}$ \\
\hline 4 & $\begin{array}{l}\text { Grains: subprolate. } \\
\text { Endoaperture: a lalongate colpus. } \\
\text { Ornamentation: a tectum perforatum or microreticulum; tectal perforations regularly } \\
\text { spaced. }\end{array}$ & $\begin{array}{l}\text { Androsaemum, Bupleuroides, } \\
\text { Psorophytum, Arthrophyllum, } \\
\text { Triadenioides, Origanifolia, } \\
\text { Hypericum }\end{array}$ \\
\hline 5 & $\begin{array}{l}\text { Grains: spheroidal or prolate-spheroidal. Oultine in polar view triangular with concave side. } \\
\text { Endoaperture: a lalongate colpus. } \\
\text { Ornamentation: a tectum perforatum or microreticulum; tectal perforations regularly spaced }\end{array}$ & Adenotrias \\
\hline 6 & $\begin{array}{l}\text { Grains: perprolate or prolate. } \\
\text { Endoaperture: a large porus, more or less circular or lolongate. } \\
\text { Ornamentation: microreticulate or reticulate; lumina regularly spaced. }\end{array}$ & Triadenioides \\
\hline 7 & $\begin{array}{l}\text { Grains: very small, prolate. } \\
\text { Endoaperture: a large lolongate (longitudinally elongated) porus. } \\
\text { Ornamentation: microreticulate or reticulate; lumina regularly spaced. }\end{array}$ & Myriandra \\
\hline 8 & $\begin{array}{l}\text { Grains: prolate. } \\
\text { Endoaperture: a very large lolongate porus or colpus. } \\
\text { Ornamentation: microreticulate and reticulate; lumina regularly spaced. }\end{array}$ & Trigynobrathys, Brathys \\
\hline 9 & $\begin{array}{l}\text { Grains: very large, subprolate or prolate. } \\
\text { Endoaperture: a more or less lalongate porus with short lateral and meridional extensions. } \\
\text { Ornamentation: reticulate; lumina regularly spaced. }\end{array}$ & Elodes \\
\hline 10 & $\begin{array}{l}\text { Grains: subprolate or prolate. } \\
\text { Endoaperture: a more or less lalongate porus with short lateral and meridional extensions. } \\
\text { Ornamentation: microreticulate; lumina regularly spaced. }\end{array}$ & $\begin{array}{l}\text { Olympia, Campylopus, Drosocarpium, } \\
\text { Oligostema, Thasia, Crossophyllum, } \\
\text { Heterophylla, Hirtella, Coridium, } \\
\text { Taeniocarpium, Hypericum, Concinna, } \\
\text { Adenosepalum, Humifusoideum }\end{array}$ \\
\hline 11 & $\begin{array}{l}\text { Grains all of irregular form and variable shape. Apertures varying in number from } 2 \text { to } 12 \text {; } \\
\text { arranged in many different ways. }\end{array}$ & Hirtella \\
\hline
\end{tabular}

cells in this family is very characteristic and found only in a few other families: Clusiaceae, Elatinaceae and Geraniaceae. Moreover, Hypericaceae (excluding Psorospermum with fleshy tegmen cells) and Clusiaceae seeds share a unique structure with large, lignified, and tabular, thick-walled stellate cells in the exotegmen. Nevertheless, Hypericaceae seeds are distinguishable from Clusiaceae seeds in that the former are generally smaller and do not present an arille.

The typical seeds in Hypericaceae (Fig. 2) are small, narrowly cylindric to ovoid-cylindric or ellipsoid, with size within the genus Hypericum ranging from 1.5 to $0.3 \mathrm{~mm}$ (Robson, 1981). They also present brownish to blackish colour due to tannin contents. Within Hypericaceae seeds, the most similar to Hypericeae are those of tribe Vismieae. Yet, Vismia seeds are generally larger $(>1 \mathrm{~mm}$ long) and present a different testa sculpturing (Mourão \& Beltrati, 2001; Arteaga, 2007). In some Harungana and Vismia species there are large, swollen, orange or black glands in the seed testa that are not present in the seeds of Hypericeae (Stevens, 2007). The seeds of the tribe Cratoxyleae described so far are cartilaginous winged with a peripheral vein, very different to those of Hypericum (Robson, 1981). In addition, the seeds of tribe Hypericeae have a particular wing venation, composition and disposition of appendages that are not found in any other member of Hypericaceae. The wing in this group is thin and papery and it is sometimes reduced to a carina, basal prolongations or an apiculus (Robson, 1981). The different Hypericum seeds have also a characteristic reticulate pattern in the testa sculpturing. The walls of the cells of the outer layer (exotesta) are more or less thickened (Ohlendorf, 1907). This pattern of wall thickening is probably the most distinctive character of Hypericum and can sometimes help to distinguish entire sections (Robson, 1981; see Table 2 and Fig. 2). In a recent cladistic analysis of Hypericum, Nürk \& Blattner (2010) used some of the seed morphological characters discussed here to reconstruct phylogenetic relationships within $H y$ pericum (Hypericeae), such as those related to the shape (cylindrical, fusiform, pear-shaped, ovoid, clavate, elongate), presence and type of appendages (carina, elaiosome, 

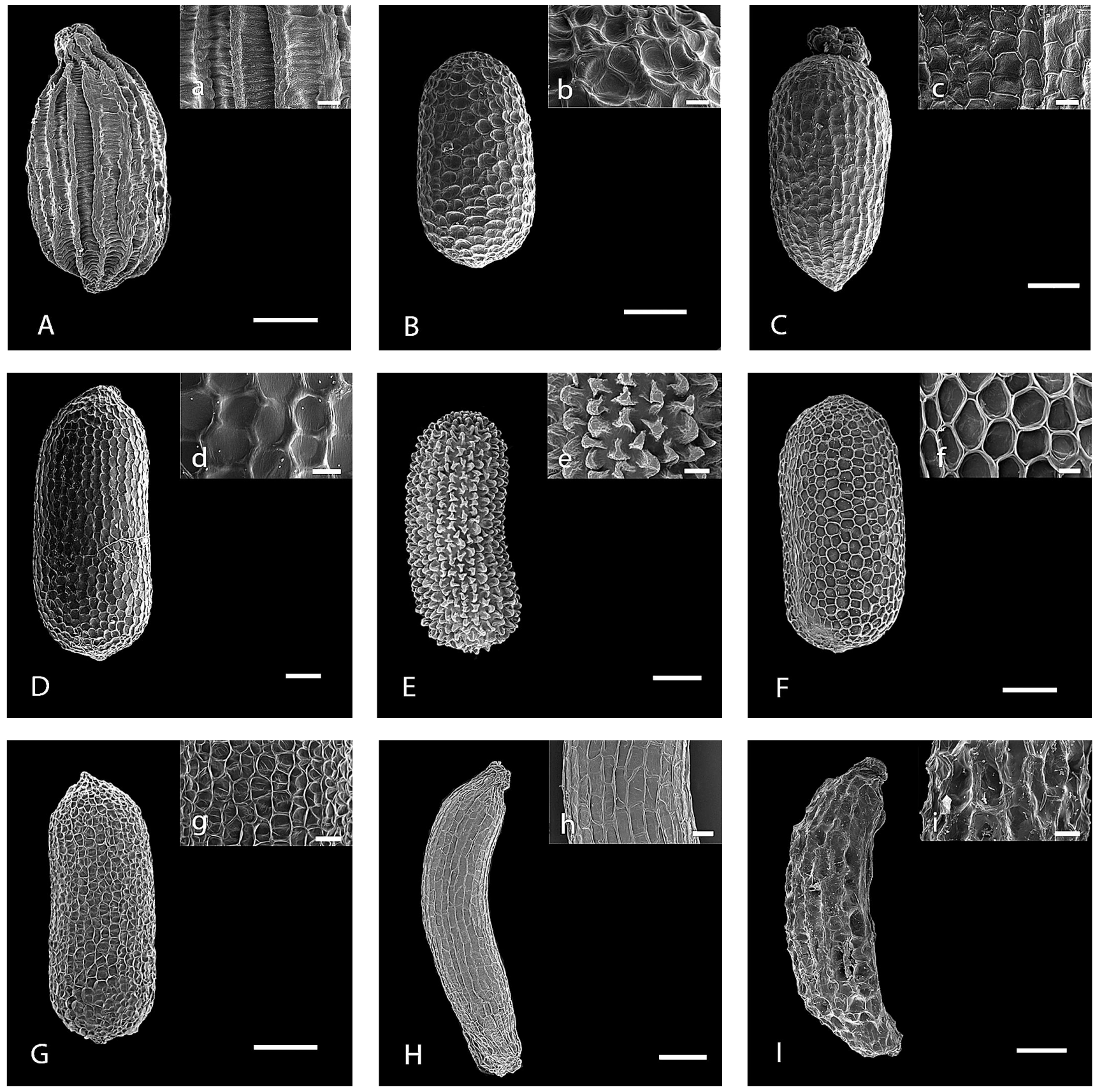

Fig. 2. Different Hypericum seeds with a detail of the sculpture: A, H. elodes; B, H. peplidifolium; $\mathbf{C}, H$. aegypticum; D, H. calycinum; E, H. hirsutum; F, H. perforatum; G, H. montanum; H, H. revolutum; I, H. canariensis (A-D; F-I = $200 \mu \mathrm{m} ; \mathrm{E}=400 \mu \mathrm{m} ; \mathrm{a}, \mathrm{c}-\mathrm{e}, \mathrm{g}-\mathrm{i}=40 \mu \mathrm{m} ; \mathrm{b}, \mathrm{f}=20 \mu \mathrm{m})$.

distal expansions, wings) and to the sculpturing of the testa (reticulate, scalariform, papillose).

In contrast to the exotesta, the endotesta in Hypericum is difficult to study and has rarely been described. Ramos Núñez (1983) studied the seeds of several Iberian species of Hypericum, and found that, while the exotesta allows distinguishing between sections, the endotesta sculpture can be specific for individual taxa. Most of the studied species exhibited a reticulate endotesta transversely oriented in relation with the longitudinal axis of the seed, which varied consistently in size, shape and surface of the cells (Ramos Núñez, 1983).

\section{THE FOSSIL RECORD OF HYPERICUM}

In this section, we re-evaluate the taxonomic assignment of the oldest seed fossil remain attributed to Hypericum, $H$. antiquum from the Upper Eocene, using diagnostic characters of extant Hypericum seeds such as the major different sculpture patterns (Table 2). We also present a chronological list of fossil remains from different geological periods that have been assigned to genus Hypericum. Although this list does not intend to be complete, especially for the most recent periods, it presents a first overview of the paleobiological literature available for the genus. While some of 
Table 2. Patterns in the sculpture of the testa in the different Hypericum sections. Adapted from Robson (1981).

\begin{tabular}{|c|c|c|c|}
\hline & Testa pattern & Description & Morphological sections \\
\hline \multirow[t]{2}{*}{ Reticulate } & $\begin{array}{l}\text { Linear-reticulate or reticulate } \\
\text { (RE-Fig. } 2 \mathrm{H})\end{array}$ & $\begin{array}{l}\text { Exotestal cells form roughly defined lines } \\
\text { and have relatively thin walls, often the } \\
\text { lines are deformed making the testa merely } \\
\text { reticulate. }\end{array}$ & $\begin{array}{l}\text { Campylosporus, Psorophytum, Ascyreia, } \\
\text { Takasagoya, Androsaemum, Inodorum, } \\
\text { Roscyna, Hypericum, Myriandra, } \\
\text { Humifusoideum, Adenosepalum, Santomasia }\end{array}$ \\
\hline & $\begin{array}{l}\text { Foveolate (FO-Fig.2F) } \\
\text { or linear foveolate }\end{array}$ & $\begin{array}{l}\text { All the walls are thickened leaving a } \\
\text { round depression between them }\end{array}$ & $\begin{array}{l}\text { Bupleuroides, Hypericum, Concinna, Olympia, } \\
\text { Campylopus, Origanifolia, Drosocarpium, } \\
\text { Oligostema, Thasia, Crossophyllum, } \\
\text { Heterophyla, Webbia, Triadenioides, } \\
\text { Ascyreia, Coridium, Taeniocarpium }\end{array}$ \\
\hline \multirow[t]{2}{*}{ Scalariform } & $\begin{array}{l}\text { Scalariform-reticulate } \\
\text { (S-RE-Fig.2C) }\end{array}$ & $\begin{array}{l}\text { Thickening confined to the longitudinal } \\
\text { cell walls }\end{array}$ & $\begin{array}{l}\text { Trigynobrathys, Myriandra, Humifusoideum, } \\
\text { Adenosepalum, Hypericum }\end{array}$ \\
\hline & $\begin{array}{l}\text { Ribbed-scalariform } \\
\text { (RI-S-Fig.2A) }\end{array}$ & $\begin{array}{l}\text { Where this longitudinal thickening is } \\
\text { more pronounce, the seed looks ridge. } \\
\text { It is often accompanied or preceded } \\
\text { by lateral elongation of the cells. }\end{array}$ & Elodes, Brathys, Trigynobrathys, Drosocarpium \\
\hline \multirow[t]{2}{*}{ Papillose } & Rugulose (RU) & $\begin{array}{l}\text { Where the outer cell walls of the foveolate } \\
\text { testa have begun to protrude }\end{array}$ & $\begin{array}{l}\text { Arthrophyllum, Coridium, Taeniocarpium, } \\
\text { Origanifolia, Adenotrias }\end{array}$ \\
\hline & Papillose (PA-Fig.2E) & $\begin{array}{l}\text { The outer cell walls have a more } \\
\text { pronounced protrusion }\end{array}$ & Hirtella \\
\hline
\end{tabular}

these fossils have been assigned to extant taxa, it is important to keep in mind that many of these taxonomic identifications are based on a limited number of characters of a few organs (pollen, seeds), and that the material is often fragmented and not well preserved. Even for perfectly conserved material, convergence of morphological traits might potentially obscure the true phylogenetic relationship between extinct and extant taxa. In an extensive study of the fossil floras of Central Europe, Mai (2001) reviewed several occurrences of Hypericum microfossils and provided a key to distinguish between seeds of some fossil (and extant) species. This key, however, was far from being exhaustive, and more importantly, it did not include some of the oldest fossil records assigned to this genus, such as $H$. antiquum or $H$. septestum (see below); thus, we do not include it here.

\section{Hypericum antiquum Balueva \& V.P. Nikitin}

To our knowledge, the oldest described fossil remains that can be unequivocally assigned to genus Hypericum corresponds to the seeds of the extinct species Hypericum antiquum Balueva \& Nikitin from the Upper Eocene (40.4 33.9 Ma) of West Siberia (Arbuzova, 2005). Surprisingly, these fossils have gone unnoticed in the Western literature, probably because they were first described in Russian in a poorly distributed book. Since these fossils have important implications for the paleobiological history of the genus (see below), we provide here a full description translated directly from the original source and a discussion of the main diagnostic characters and affinities used to assign this species to other extant taxa (Fig. 3).

Holotype: seed, Upper Eocene, Uzhanikha, borehole 1, depth 250 m (West Siberia), specimen 18/1, collection Kpr.61-1-250 [NG].

Locality. Uzhanikha, Novosibirskaya oblast, Russia.

Diagnosis. Seeds 0.4-0.65 × 0.25-0.35mm, anatropus, cylindrical, often flattened, longitudinally slightly bent towards the raphe. Meshes of the surface narrow; longitudinally elongated, hexagonal. The elongated cells of the testa form a mesh sculpture of the surface. Their arrangement on the surface of the seed gives the impression of a crosshatched line. Longitudinal walls of the cells are higher than the transverse ones, forming thin meridional ribs on the seed surface. One end is rounded with a small tubercle slightly shifted to the ventral side. The other end is slightly narrowed with a little tubercle. The seed case is relatively thin. The seed is black.

The description above and the original drawing of the fossil seed seem to present a completely preserved exotesta (Fig. 3A), from which a more detailed view of the cells is also provided (Fig. 3B). No mention about the endotesta is given. The size, colour, shape and testa sculpturing of these fossils are all characteristic of the seeds of the genus Hypericum (Fig. 2). Yet, the author (Arbuzova, 2005) considers $H$. antiquum as a different species from other known Oligocene Hypericum fossils (e.g., H. septestum, see below) and did not assign it to any extant representative. However, we think that the characteristic sculpturing pattern of the testa, with meridional ribs on the seed surface (Fig. 3), resembles those of some extant species, especially the pattern RI-S that is characteristic of the following sections: Elodes, Brathys, Trigynobrathys and Drosocarpium (Table 2). Nevertheless, we found some ambiguities in the original description: there are no meridional or longitudinal ribs in the detail of the exotesta (Fig. 3B), and although the axis of elongation of the palisade cells is described as longitudinal in the text, it appears transversal in the original drawing (Fig. 3B). In a subsequent publication, Nikitin (2006) seemed to correct this error and described the seeds as "made up of transversely elongated cells". We also could not find any information about the number of cells between ribs in the text. 


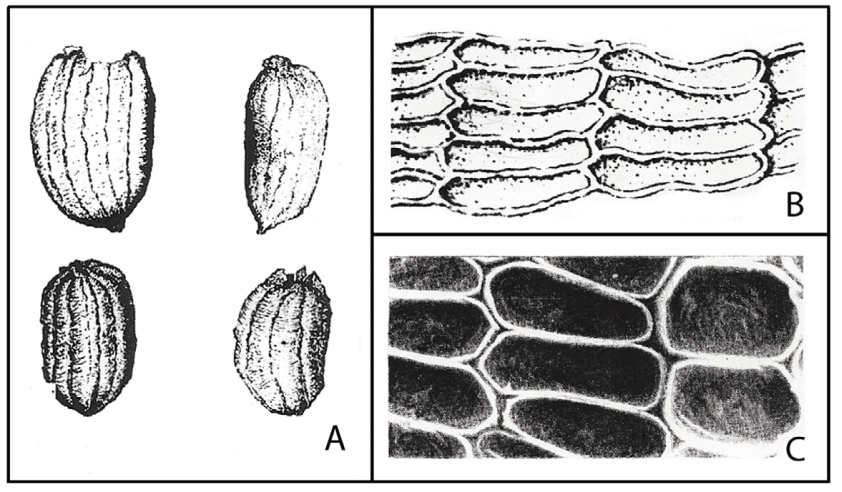

Fig. 3. A, fossil seeds of Hypericum antiquum; $\mathbf{B}$, detail of the palisade cells of $H$. antiquum fossil seeds; $\mathbf{C}$, palisade cells of the fossil specie Triadenum virginicum $(=\mathrm{H}$. virginicum) (reproduced with permission from Arbuzova, 2005)

\section{OTHER FOSSILS ASSIGNED TO HYPERICUM}

\section{Paleogene}

There is a rich record of different fossil taxa recorded for this period. An Early Paleocene (65.5-61.7 Ma) Hypericum seed fossil has been cited in NE China (Hao \& al., 2010). However, this work did not include any morphological description or illustration of the fossil and it is difficult to confirm whether it belongs to Hypericum and not to any other related group. The seed remains known as $H$. bornense $\mathrm{Mai}$ in Mai \& Walter (1978) and H. septestum Nikitin (Dorofeev, 1957; Dorofeev, 1963; Mai \& Walther, 1978; Mai, 1997) appear in different Early to Late Oligocene sites (33.9-23 Ma) in Germany (Saxony) and in the Russian Federation (Tomsk). In particular, $H$. septestum seeds are a common element in the fossil record of Hypericum until the Pliocene, and have been described from different sites across Europe, including the Early Miocene (23-16 Ma) of the Czech Republic (Teodoridis, 2002, 2003), Germany (Gümber \& Mai, 2002), Poland (Holý, 1974; Kvaček \& Teodoridis, 2003) and Russia (Dorofeev, 1963), the Mid Miocene (16-11.6 Ma) of Bulgary (Palamarev \& al., 2005) or the Pliocene (5.3-2.6 Ma) of Italy (Martinetto \& al., 2007). The seeds of H. septestum are generally small, oval with a reticulate surface consisting of polygonal cells (Teodoridis, 2003). Remains attributed to this name have been variously assigned to different extant species. Negru (1972) and Dorofeev (1963) have compared them to $H$. scabrum L. and $H$. aegypticum L. respectively, whereas Gümbel \& Mai (2002) and Arbuzova (2005) considered this species to be more similar to Triadenum virginicum $\mathrm{L}$. $(=H$. virginicum $\mathrm{L}$.).

Seeds of Hypericum coriaceum Nikitin have been described from several sites from the Late Oligocene onwards in Russia and Belarus (Nikitin, 1948; Dorofeev, 1959, 1963, 1979; Yakubovskaya, 1982; Velichkevich, 1982, 1990). The identity of this paleotaxon has been put in doubt by Mai (2001), who suggests to exclude it from the Hypericum fossil record and assign it instead to genus Ludwigia (Onagraceae).

Fossil seeds of Hypericum miocenicum Dorof. emend.
Mai are recorded from the Late Oligocene (28.4-23 Ma) of Saxonia and Lusatia (Germany), but also from the Late Miocene (11.6-5.3 Ma) of Poznan (Poland) and the Pliocene of Thuringia (Germany) (Mai, 2001). Hypericum miocenicum differs from the more frequent $H$. septestum in the shape of the surface cells being more quadrangular to rectangular with the wall of the foveoles thinner (Mai, 2001). Finally, fossil pollen of Hypericum (no other assignment) has been described form the Lower Oligocene (Sant Gallart Formation) in the Ebro Basin (Cavagnetto \& Anadón, 1996).

\section{Neogene}

There are many fossil remains identified as Hypericum from this period (Miocene-Pliocene), with some of them assigned to present taxa. We believe, however, that the morphological affiliation of some of these records attributed to extant Hypericum species needs of further clarification.

The seeds of Hypericum bolyi Friis are cited in Central European sites from the Lower to Upper Miocene (23-5.3 Ma) (Friis, 1985; Mai, 1999; Mai, 2000; Meller \& Hoffman, 2004). Hypericum tertiaerum Nikitin fossil seeds also appear during the same period in East and Central Europe and Siberia (Dorofeev, 1963; Łańcucka-Środoniowa \& al., 1981; Van der Burgh, 1987; Baranowska-Zarzycka, 1988; Dyjor \& al., 1992; Mai, 2000, 2001). This species is also frequently found in Pliocene sites from the same regions (Nikitin, 1957; Dorofeev, 1979; Jahn \& al., 1984; Yakubovskaya, 1984; Mai \& Walther, 1988; Velichkevich, 1990; Mai, 2001; Gümbel \& Mai, 2004; Arbuzova, 2005). According to Velichkevich \& Zastawniak (2003) the East-Asiatic $H$. japonicum Blume and the North American H. virginicum L. and $H$. tubulosum Walt. are two extant species of Hypericum whose seeds most closely resemble those of Hypericum tertiaerum.

Other Miocene Hypericum microfossils include: $H$. tanaiticum P. Dorof., H. tambovicum P. Dorof. in Russia, H. cf. balearicum L., H. cf. scabrum L. H. cf. androsaemum L. in Moldavia, and H. cf. acutum L. in Ukraine (Arbuzova, 2005); H. welzowense Mai in Germany (Mai, 2001), H. aff. ponticum Lipsky in Bulgaria (Palamarev \& al., 2005), and $H$. cf. bumifusum in northern Italy (Kovar-Eder \& al., 2006), as well as formally undescribed fossil remains from the Early Miocene of China (Zhao \& al., 2004). In the Iberian Peninsula there are also pollen remains from the Mid Miocene (Barrón \& al., 2010).

More recent records include the Pliocene seeds of $H$. foveolatum Dorof. from Russia (Dorofeev, 1986; Gümbel \& Mai, 2004) and Belarus (Velichkevich \& Zastawniak, 2003; Arbuzova, 2005), H. androsaemun L. fossilis (Gümbel \& Mai, 2004), and fossil seeds of $H$. perforatum L. also from Russia (Arbuzova \& al., 2005), which the authors mentioned to be identical to extant $H$. perforatum seeds. The fossil species H. foveolatum has been compared (Dorofeev, 1986) to extant species from Europe (H. quadrangulum L., H. elegans Willd., H. tetrapterum Fries), East Asia (H. attenuatum Choisy, H. kamtschaticum Ldb., H. yezoënse Maxim.), and North America (H. nudiflorum Michx., H. microsepalum 


\section{A) Paleogene}

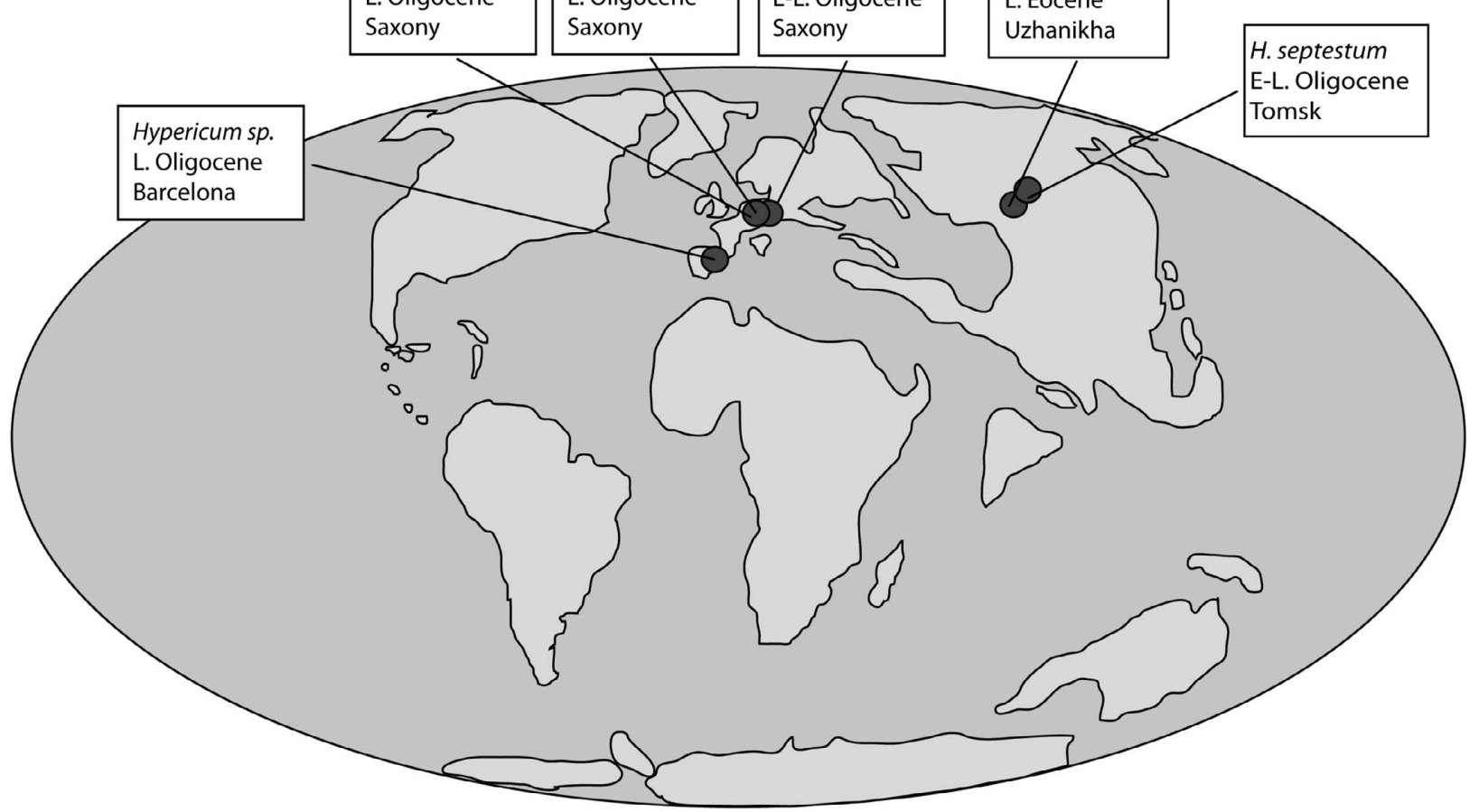

\section{B) Neogene}

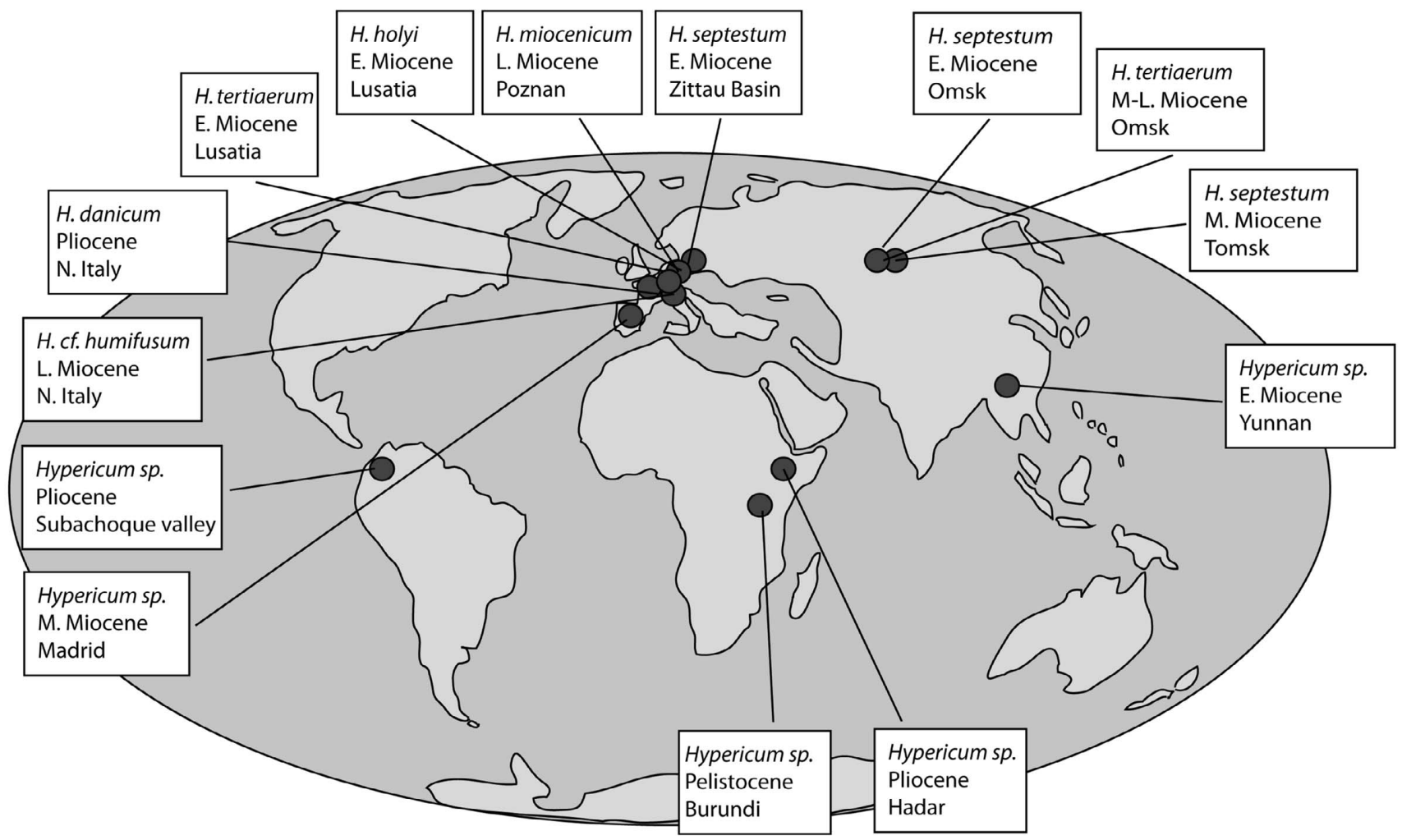

Fig. 4. Map showing the approximate distribution of the most relevant fossil remains of Hypericum discussed in relation to palaeogeographic reconstructions: A, Paleogene (Eocene-Oligocene); B, Neogene (Miocene-Pliocene). 
Torr. \& Grey), although none of these species have the testa surface cells morphologically identical to those of the fossil (Velichkevich \& Zastawniak, 2003). Other fossils include a macrofossil leaf (H. xylosteifolium (Spach.) N. Robson) from the Upper Pliocene of Georgia (Arbuzova, 2005); and a fossil seed of $H$. danicum Friis (Mai, 1995) along with other Pliocene Hypericum seed morphotypes found in Italy (Martinetto \& al., 2006; Ciangherotti \& al., 2007), Germany (Reid \& Reid, 1915) and Belarus (Velichkevich \& Zastawniak, 2003).

Apart from seeds and leaves, fossil pollen has been described from the Pliocene of diverse parts of the world, including Colombia (Wijninga \& Kuhry, 1989) and Ethiopia (Bonnefille \& al., 1987). Pleistocene fossil pollen has been described from sites in the African Republic of Burundi (Bonnefille \& Riollet, 1988; Bonnefille \& al., 1992). However, Pleistocene pollen records are too abundant to review them in this work. If we take into account the amount of Hypericum citations in the Neogene fossil record, the most striking gap to our knowledge is the lack of fossil evidence available for Hypericum in North America until the Pleistocene: seeds of Triadenum virginicum (= Hypericum virginicum) represents the earliest record for the genus (Miller $\&$ Calkin, 1990).

Finally, we should comment the occurrence of some seed remains that after further revision have been excluded from the fossil record of Hypericum (Mai, 2001): H. cf. ascyron L.C. \& E. M. Reid (1915), H. cantalense Reid (1923), H. pliocenicum Nikitin (1935) and H. rostriferum Jakubovskaja (1988).

\section{PALAEOGEOGRAPHIC IMPLICATIONS}

The palaeogeographical distribution of the main fossil remains of Hypericum discussed in this survey illustrates the evidence for the long history of this genus (Fig. 4). Interestingly, many of the above-mentioned fossils have been assigned to species that are not presently distributed in the area in which the fossil was found. For example, remains attributed to $H$. septestum (described from Siberia, Europe) have been assigned to different extant species, none of which overlap in distribution with the fossil sites where the original species was described: e.g., H. scabrum L., is distributed from Lebanon to China, $H$. aegypticum $\mathrm{L}$. occurs in northern Africa, and Triadenum virginicum (L.) Raf. ( $H$. virginicum L.) is distributed in eastern North America. Another interesting example is the fossil remains attributed to $H$. cf. balearicum described from sites in Moldavia. The species under this name is now endemic to the Balearic Archipelago in the Western Mediterranean region. Many of these problematic fossils should be subject to careful revision before being assigned to extant species (Mai, 2001). It is also interesting to note that most fossil remains described here, especially the oldest records, are from sites in Central Europe and Russia, which could be a potential bias of the fossil record. For example, the lack of fossil record of $\mathrm{Hy}$ pericum in North America is surprising since several species of Hypericum are endemic to this region. Despite this potential bias, we think that the distribution of the fossil record of Hypericum (see below) remains an important tool to gives us clues on its past distribution and biology.

The discovery of the fossil species $H$. antiquum in a site in Siberia dated from the Upper Eocene suggests that lineages of Hypericum were present in northern Eurasia during a period when the climate was considerably warmer and humid than today, following the Early Eocene Warming Event dated 55 million years ago (Wolfe, 1975; Tiffney, 1985a). At that time a "boreotropical" forest belt characterised by a mixture of deciduous hardwoods and evergreen subtropical elements, extended from Europe to North America and Asia, across a narrower Atlantic Ocean and a warmer Beringia (Wolfe, 1969, 1975, 1978; Tiffney 1985a, 1985b; Sanmartín \& al., 2001). The global climate cooling that started with the Terminal Eocene Event at the end of the Eocene extirpated much of this forest from Siberia and other Northern Hemisphere regions, leaving extant remnants in eastern Asia and eastern North America (Tiffney, 1985a; Sanmartín \& al., 2001). It seems plausible that the oldest lineages of Hypericum were part of this forest, or of its successor, the "mixed-mesophytic forest" (Tiffney, 1985a), as evidenced by the presence of fossil remains H. bornense and H. septestum in Lower Oligocene sites of Germany and West Russia. These findings also suggest that the Hypericum species currently present in Siberia are derived from younger, more recently diverged lineages, while older Northern European lineages would have become extinct during the glaciations of the Quaternary period (Sanmartín \& al., 2001). Moreover, if our assumption is true, and Hypericum stem lineages were part of the Northern Hemisphere boreotropical forest belt, we might expect to find some Paleogene fossils in North America. A phylogeny-based biogeographic reconstruction that includes all these fossil remains is needed to confirm the importance of these findings and our paleobiological conclusions (Meseguer \& al., in prep.).

\section{ACKNOWLEDGEMENTS}

This work has been funded by the Spanish Ministry of Education and Science (project CGL2009-13322-C03-01/BOS) and PhD research grant AP-2007-01698 to A.S. Meseguer. We are very grateful to C.L. Anderson and A. Hvalj for help with the fossil record search; S. Rezinciuc, M. Bojidarova, and A. Hilpold for the Russian and German translations; A. Ramos Nuñez, A. Hilpold, editors E. Barrón and J. Fuertes for valuable comments on the manuscript. We are also grateful to Y. Ruiz for technical assistance with SEM, and the RJB-CSIC Madrid herbarium (MA) for allowing access to seed material.

\section{BIBLIOGRAPHY}

Arbuzova, O. 2005. Hypericum L. In: Budantsev, L. (eds.), Iskopaemye tsvetkovye rastenija Rossii i sopredel'nyh gosudarstv [Fossil flowering plants of Russia and adjacent countries], Vol. 4 Nyctaginaceae-Salicaceae. Izdatelstvo Nauka Leningradskoe otd-nie, 1974-. Leningrad. (In Russian).

Arteaga, L.L. 2007. Vismia glaziovii Ruhl. (Guttiferae) seed size and its relationship with the germination speed and seedling size. Revista Peruana de Biología 14: 17-20.

Baranowska-Zarzycka, Z. 1988. Main features of the Pliocene fruit-seed flora from Ruszów near Z ary (West Poland). Acta Palaeobotanica 28: $23-27$. 
Barrón, E., Rivas-Carballo, R., Postigo-Mijarra, J.M., Alcalde-Olivares, C., Vieira, M., Castro, L., Pais, J. \& Valle-Hernández, M. 2010. The Cenozoic vegetation of the Iberian Peninsula: A synthesis. Review of Palaeobotany and Palynology 162: 382-402 (SI).

Barros, M. \& Ramos, A. 1984. Estudio del polen de las especies de Hypericum sect. Hirtella Stef. en la Península Ibérica y Baleares. V Simposio de Palinología. APLE. Resúmenes. Córdoba.

Bonnefille, R., Vincens, A. \& Buchet, G. 1987. Palynology, stratigraphy and palaeoenvironment of a Pliocene hominid site (2.9-3.3 M.Y.) at Hadar, Ethiopia. Palaeogeography, Palaeoclimatology, Palaeoecology 60: 249-281.

Bonnefille, R. \& Riollet, G. 1988. The Kashiru pollen sequence (Burundi). Palaeoclimatic implications for the last $40000 \mathrm{yr}$ B.P. in tropical Africa. Quaternary Research 30: 19-35.

Bonnefille, R., Chali, F., Guiot, J. \& Vincens, A. 1992. Quantitative estimates of full glacial temperatures in equatorial Africa from palynological data. Climate Dynamics 6: 251-257.

Cavagnetto, C. \& Anadón, P. 1996. Preliminary palynological data on floristic and climatic changes during the Middle Eocene-Early Oligocene of the eastern Ebro Basin, northeast Spain. Review of Palaeobotany and Palynology 92: 281-305.

Crepet, W.L. \& Nixon, K.C. 1998 . Fossil Clusiaceae from the late Cretaceous (Turonian) of New Jersey and implications regarding the history of bee pollination. American Journal of Botany 85: 1122-1133.

Ciangherotti, A., Esu, D., Martinetto, E. \& Giuntelli, P. 2007. The remarkable Middle Pliocene non-marine mollusc record from Ceresole d'Alba, Piedmont, north-west Italy: Biochronology, palaeobiogeography and palaeoecology supported by fossil plants. Geobios 40: 573-587.

Clarke, G.C.S. 1975. Irregular pollen grains in some Hypericum species. Grana 15: 117-125.

Clarke, G.C.S. 1976. The northwest European pollen flora, 7 Guttiferae. Review of Paleobotany and Palynology 21: 125-142.

Clarke, G.C.S. 1981. 4. Pollen morphology. In: Robson, N.K.B., Studies in the genus Hypericum L. (Guttiferae) 2. Characters of the genus. Bulletin of the British Museum of Natural History (Botany) 8: 115-118.

Corner, E.J.H. 1976a. The Seeds of Dicotyledons, Vol. 1. Cambridge University Press, Cambridge.

Corner, E.J.H. 1976b. The Seeds of Dicotyledons, Vol. 2. Cambridge University Press, Cambridge.

Davis, C.C., Webb, C.O., Wurdack, K.J., Jaramillo, C.A. \& Donoghue, M.J. 2005. Explosive radiation of Malpighiales supports a mid-Cretaceous origin of modern tropical rain forests. Amer. Naturalist 165: E36-E65.

Dorofeev, P.I. 1957. Novye dannye o pliotsenovoy flore Kamy (New data on the Pliocene flora of Kama). Doklady Akademii Nauk SSSR 117: 487-490. (In Russian).

Dorofeev, P.I. 1959. Materialyk poznaniyu miotsenovoy flory Rostovskoy oblasti (summary: Contribution to the study of Miocene floras of the Rostov region). Problemy botaniki (The problems of Botany) 4: 143-189. (In Russian).

Dorofeev, P.I. 1963. Tretichnye flory Zapadnoi Sibiri (Tertiary Floras of Western Siberia). Izdatelstvo Akademii Nauk, Moscow/Leningrad. $343 \mathrm{pp}$.

Dorofeev, P.I. 1979. O pliotsenovoy flore s. Dan'shino na Donu (On the Pliocene flora of the vill. Dan'shino on the Don): 87-94. In: Raskatov G.I. (eds.), Problemy Antropogena tsentralnykh rayonov Russkoy platformy (The Problems of the Antropogene of central districts of the Russian platform). Izdatelstvo Voronezh University, Voronezh. (In Russian).

Dorofeev, P.I. 1986. Iskopaemye Potamogeton (Fossil Potamogeton). Izdatelstvo Nauka, Leningrado. (In Russian).

Dyjor, S., Kvaček, Z., Łańcucka-Środoniowa, M., Pyszyński, W., Sadowska, A. \& Zastawniak, E. 1992. The younger Tertiary deposits in the Gozdnica region (SW Poland) in the light of recent palaeobotanical research. Polish Botanical Studies 3: 1-129.

Friis, E.M., 1985. Angiosperm fruits and seeds from the Middle Miocene of Jutland (Denmark). Biologiske Skrifter, Det Kongelige Danske Videnskabernes Selskab 24: 1-165.

Gümbell, F. \& Mai, D.H. 2002. Neue Pflanzenfunde aus dem Tertiär der Rhön. - Teil 1: Miozäne Fundstellen. Mitteilungen aus dem Museum für Naturkunde in Berlin, Geowissenschaftliche Reibe 5: 345-384.
Gümbell, F. \& Mai, D.H. 2004. Neue Pflanzenfunde aus dem Tertiär der Rhon.- Teil 2: Pliozäne Fundstellen. Mitteilungen aus dem Museum für Naturkunde in Berlin, Geowissenschaftliche Reibe 7: 175-220.

Hao, H., Ferguson, D.K., Feng, G-P., Ablaev, A., Wang, ·Y-F. \& Li, C-S. 2010. Early Paleocene vegetation and climate in Jiayin, NE China. Climatic Change 99: 547-566.

Ho, S.Y.W. 2007. Calibrating molecular estimates of substitution rates and divergence times in birds. Journal of Avian Biology 38: 409-414.

Holý, F. 1974. Neogénni mastixioidní květena surchního slojovébo pásma z lomu Kristina (Hrádek n. N.). Dissertation thesis, Department of Palaoentology, National Museum, Prague. 131pp.

Jahn, A., Łańcucka-Środoniowa, M. \& Sadowska, A. 1984. Stanowisko utworów plioceńskich w Kotlinie Kłodzkiej (summary: The site of Pliocene deposits in the Kłodzko Basin, Central Sudetes). Geologia Sudetica 18: 7-43.

Khan, H.A. 1969. Pollen morphology of Indian Hypericaceae. Journal of Palynology. 5: 97-99.

Kovar-Eder, J., Kvaček, Z., Martinetto, E. \& Roiron, P. 2006. Late Miocene to Early Pliocene vegetation of southern Europe (7-4 Ma) as reflected in the megafossil plant record. Palaeogeography, Palaeoclimatology, Palaeoecology 238: 321-339.

Kvaček, Z. \& Teodoridis, V. 2003. Tertiary macrofloras of the Bohemian Massif: a review with correlations within Boreal and Central Europe. Bulletin of Geosciences 82: 383-408.

Łańcucka-Środoniowa, M. 1981. Macroscopic plant remains from the Miocene deposits at Stara Wieśnear Wilamowice (southern Poland). Acta Palaeobotanica 21: 115-126.

Mai, D.H. 1995. Palaeocarpological investigations in the Villafranchian (Pliocene) of Italy. Bollettino Museo Regionale di Scienze Naturali 13: 407-437.

Mai, D.H. 1997. Die Oberoligozänen Floren am Nordrand der Sächsischen Lausitz. Palaeontographica B 244: 1-124.

Mai, D.H. 1999. Die untermiozänen Floren aus der Spremberger Folge und dem 2. Flözhorizont in der Lausitz. Teil I: Farnpflanzen, Koniferen und Monokotyledonen. Palaeontographica B 250: 1-76.

Mai, D.H. 2000. Die untermiozänen Floren aus der Spremberger Folge und dem 2. Flözhorizont in der Lausitz. Teil III: Dialypetale und Sympetale. Palaeontographica B 253: 1-106.

Mai, D.H. 2001. Die mittelmiozänen und obermiozänen Floren aus der Meuroer und Raunoer Folge in der Lausitz. III. Fundstellen und Palaeobiologie. Palaeontographica B 258:1-85.

Mai, D.H. \& Walther, H. 1978. Die Floren der Haselbacher Serie im Weisselster Becken (Bezirk Leipzig, DDR). Abhandlungen des Staatlichen Museums für Mineralogie und Geologie zu Dresden 28: 1-200.

Mai, D.H. \& Walther, H. 1988. Die pliozänen Floren von Thüringen. Quartärpaläontologie 7: 55-295.

Martinetto, E., Scardia, G. \& Varrone, D. 2007. Magnetobiostratigraphy of the stura di lanzo fossil forest succession (Piedmont, Italy). Revista Italiana di Paleontologia e Stratigrafia 119: 109-125.

Mártonfi, P., Janíková, M. \& Zezula, I. 2002. Palynological analysis of seven Hypericum taxa. Biologia, Bratislava 57: 455-460.

Meller, B. \& Hofmann, C.C. 2004. Paleoecology of Diaspore- and Palynomorph assemblages form Late Miocene lake sediments (Mataschen near Fehring, East Styria, Austria). Joannea Geologie und Paläontologie 5: 177-217. (In German).

Miller, N.G. \& Calkin, P.E. 1992. Paleoecological interpretation and age of an interstadial lake bed in western New York. Quaternary Research 31: 75-88.

Mourão, K.S. \& Beltrati, C. 2001. Morphology and anatomy of developing fruits and seeds of Vismia guianensis (Aubl.) Choisy (Clusiaceae). Revista Brasileira de Biologia 61: 147-158.

Matzk, F., Meister, A., Brutovska, R. \& Schubert, I. 2001. Reconstruction of reproductive diversity in Hypericum perforatum L. opens novel strategies to manage apomixis. The Plant Journal 26: 275-282.

Negru, A.G. 1972. Rannesarmatskaya flora severovostoka Moldavii (The Early Sarmatian flora from North-East of Moldavia). Shtiintsa, Kishinev. 169 pp. (In Russian).

Nikitin, P.A. 1948. Pliocenovye flory s reki Obi v rayonie Tomska (Pliocene floras from Ob river near Tomsk). Doklady Akademii Nauk SSSR 61: 1103-1106. (In Russian).

Nikitin, P.A. 1957. Pliotsenovye i chetvertichnye flory Voronezbskoy oblasti 
(Pliocene and Quaternary floras of Voronezh district). Izdatelstvo Akademii Nauk SSSR, Moskva-Leningrad. (In Russian).

Nikitin, V.P. 2006. Paleocarpology and stratigraphy of Paleogene and Neogene strata of Asian Russia. Izdatelstvo Akademii "Geo”, Novosibirsk. (In Russian).

Nürk, N.M. \& Blattner, F.R., 2010. Cladistic analysis of morphological characters in Hypericum (Hypericaceae). Taxon 59: 1495-1507.

Ohlendorf, O. 1907. Beiträge zur Anatomie und Biologie der Früchte und Samen einheimischer Wasser-und Sumpfpflanzen. Inaugural Dissertation, Friedrich-Alexander-Universität, Erlangen.

Palamarev, E., Bozukov, V., Uzunova, K., Petkova, A. \& Kitanov, G. 2005. Catalogue of the Cenozoic plants of Bulgaria (Eocene to Pliocene). Phytologia Balcanica 11: 215-364.

Ramos Núñez, A. 1983. Estudio biosistemático del género Hypericum L. (Guttiferae) en la Península Ibérica e Islas Baleares. 1. Caracteres seminales. Trabajo del Departamento de Botánica 12: 45-62.

Reid, C. \& Reid, E.M. 1915. The Pliocene floras of the Dutch-Prussian border. Mededeelingen van de Rijksopsporing van Delfstoffen 6: 1-178.

Reid, E.M. 1923. Nouvelles recherches sur les graines du Pliocéne inferieur du Pont-du-Gail (Cantal). Le Bulletin de la Société géologique de France IV, 23: 305-355.

Robson, N.K.B., 1977. Studies in the genus Hypericum L. (Guttiferae). 1. Infrageneric classification. Bulletin of the British Museum of Natural History (Botany) 5: 295-355.

Robson, N.K.B. 1981. Studies in the genus Hypericum L. (Guttiferae). 2. Characters of the genus. Bulletin of the British Museum of Natural History (Botany) 8: 55-226.

Ruhfel, B.R., Bittrich, V., Bove, C.P., Gustafsson, M.H.G., Philbrick, C.T., Rutishauser, R., Xi, Z \& Davis, C.C. 2011. Phylogeny of the clusioid clade (Malpighiales): evidence from the plastid and mitochondrial genomes. American Journal of Botany 98: 306-325.

Sanmartín, I., Enghoff, H. \& Ronquist, F. 2001. Patterns of animal dispersal, vicariance and diversification in the Holarctic. Biological Journal of the Linnean Society 73: 345-390.

Stevens, P.F. 2007. Hypericaceae. In: Kubitzki, K. (eds.), The families and genera of vascular plants, Vol. 9. Pp. 194-201. Springer, Berlin, Heidelberg.

Teodoridis, V. 2002. Notice about a revision of the Early Miocene carpological material from the Czech part of the Zittau Basin. Zprávy o geolofických výzkumech v roce: 157-158.

Teodoridis, V. 2003, Early Miocene carpological material from the Czech part of the Zittau Bassin. Acta Palaeobotanica 43: 9-49.

Thomas, J.L. 1970. Haploid a diploid pollen in Hypericum patulum. Journal of the Arnold Arboretum 51: 247-250.
Tiffney, B.H. 1985a. Perspectives on the origin of the floristic similarity between eastern Asia and eastern America. Journal of the Arnold Arboretum 66: 73-94.

Tiffney, B.H. 1985b. The Eocene North Atlantic land bridge: its importance in Tertiary and modern phytogeography of the Northern Hemisphere. Journal of the Arnold Arboretum 66: 243-273.

Van der Burgh, J. 1987. Miocene floras in the lower Rhenish basin and their ecological interpretation. Review of Palaeobotany and Palynology 52: 299-366.

Velichkevich, F.Yu. 1982. Pleystotsenovye flory lednikovykh oblastey Vostochno-Evropeyskoy ravniny (The Pleistocene floral of glacial areas of the East European Plain). Nauka i Tekhnika, Minsk. (In Russian).

Velichkevich, F.Yu. 1990. Pozdnepliotsenovaya flora Dvortsa na Dnepre (The Late Pliocene flora of Dvorets on the Dnieper River). Nauka i Tekhnika, Minsk. (In Russian).

Velichkevich, F.Yu. \& Zastawniak, E. 2003. The Pliocene flora of Kholmech, south-eastern Belarus and its correlation with other Pliocene floras of Europe. Acta Palaeobotanica 43: 137-259.

Wijninga, V.M. \& Kuhry, P. 1990. A Pliocene flora from the Subachoque Valley (Cordillera Oriental, Colombia). Review of Palaeobotany and Palynology 62: 249-290.

Wolfe, J.A. 1969. Neogene floristic and vegetational history of the Pacific North-west. Madroño 20: 83-110.

Wolfe, J.A. 1972. An interpretation of Alaskan Tertiary floras. In: Graham, A. (eds.), Floristics and Paleofloristics of Asia and eastern North America: 201-233. Elsevier, Amsterdam.

Wolfe, J.A. 1975. Some aspects of plant geography of the northern hemisphere during the Late cretaceous and Tertiary. Annals of the Missouri Botanical Garden 62: 264-279.

Yakubovskaya, T.V. 1982. Pliotsenovye flory Belorusskovo Podneprovýa (Pliocene floras of Byelorussian Podnieprovye): 34-61. In: Velichkevich, F.Yu. (eds.) Paleokarpologicheskie issledovaniya kaynozoya (Palaeocarpological investigations of Cenozoic). Nauka i Tekhnika, Minsk. (In Russian).

Yakubovskaya, T.V. 1984. Ocherk neogena i rannevo antropogena Ponemanya (Sketch of Neogene and Early Antropogene of the Ponemanye). Nauka i Tekhnika, Minsk. (In Russian).

Zhaoa, L.C., Wanga, Y.F., Liua, C.J. \& Li, C.S. 2004. Climatic implications of fruit and seed assemblage from Miocene of Yunnan, southwestern China. Quaternary International 117: 81-89.

Associate Editor: Eduardo Barrón Received: 25-I-2012

Accepted: 14-IV-2012 